\title{
Uber
}

By TERESA PEPE

Join Us and Work with Uber or Careem with your private car and your driving licence and reach a monthly pay of $12000 \mathrm{EP}$, we accept cars from 2010, and [driver's] age from 21 to 60, for inquiries call 0101404199901118866023 if the lines are busy you can contact us on Whats[app] on 01014041999 or 01118866023 . (Mubawwaba Mașrī)

With this advertisement, the San Francisco-based company Uber and its Dubai-based counterpart Careem are hiring new drivers in Egypt.

Uber is an app-based car service that allows citizens to use their private car, driving licence and smartphones to offer fellow citizens a private car-ride. Likewise, riders can order the service, pay and rate their trip experience directly through their $\lambda$ Mobile Phones]. Uber was originally launched in the USA in 2010 (Hartmans \& McAlone). The company applies a new economic model, the so-called "sharing economy," that implies that private citizens exchange services with each other via an online platform [ 7 Crowdfunding]. In 2011, the company Careem adjusted the same idea for the Middle Eastern market. Since 2015, Uber and Careem have become widely used in Egypt as well, especially among upper-middle class youth who can afford a smartphone and a credit card. The service is mostly available in the central neighbourhoods of Cairo and Alexandria, and in the suburban gated communities of Cairo, where public transportation is not provided by the State [ $\nearrow$ Gated Communities / Compounds]. In Tunisia, as in many other world countries, the company is banned, as the national labour union strives to protect their members from competition with unlicensed drivers working for Uber and similar companies.

In Egypt, the app-based car service co-exists with the regular "white taxis." Those are still available for the majority of the population who cannot afford a credit card and a smartphone [ $\lambda$ Affluence $v s$. Destitution]. But unlike regular taxis, Uber and Careem offer a different mode of booking the service, navigating the city and interacting with the driver. The young, upper-middle class digital-savvy section of the Egyptian population, and especially women, perceive this difference as a significant improvement in the quality of the taxi service.

First of all, with Uber and Careem, one does not need to wave to a taxi, while standing on the side of a busy street. More importantly, there is no need to engage in tiring negotiations over the route and the fare that very often end in yelling and cursing - the arrangement takes place through the app. The customer/user enters the destination into the box labelled "where to?" near the top of the screen and confirms destination and exact pickup point by dropping a blue pin on the map. The app automatically finds an available driver nearby, showing his name and picture, and previous customers' ratings. It also gives an estimate of how long it takes to get there and how much it will cost. With Uber, the cost of a ride depends on the distance and time of the ride. The more people who request an Uber ride at the same time, the more expensive a fare gets[ ZZahma]. With Careem, the cost of a ride depends on the route and the type of car ordered. Once the customer has booked the ride, the driver heads to

Journal of Arabic and Islamic Studies • 21 (2021) - Themed Section In2016: *272-*277 (C) Teresa Pepe, Dept. of Cultural Studies and Oriental Languages (IKOS), University of Oslo 
the pick-up point, and gives the customer a phone call once he has reached the agreed location.

There is a certain difference in terms of comfort and security between Uber and white taxis. The white Cairene taxis are usually old and very often saturated with smoke and dust. Many taxi drivers smoke heavily while sitting for hours in the car because of the traffic jam. In addition, taxi rides in Egypt tend to be accompanied by loud Quran recitation or Arabic pop music played on the radio [ $\triangle$ Pop Music]. In contrast, Uber cars are clean, new and perfumed. Smoking is forbidden for both the rider and the driver. Noisy music and radio are not allowed, and the rider is asked beforehand whether he/she would like music or radio on.

Most importantly, the Uber ride implies a different interaction between the rider and the driver. Egyptian taxi drivers are known for their inclination to exchange funny anecdotes and more serious stories, as Khālid al-Khamīsī has portrayed in his book Taxi in 2007. Taxi drivers tend to ask nosy questions about the rider's marriage status, religion, and political views [ 7 Freedom vs. Constraint (Individuality vs. Collectivity)]. A Facebook user denounces that some taxi drivers have even taken the initiative to take customers to the police after they have expressed anti-governmental views (ANDEEL) [ $\nearrow$ The Honourable Citizen]. In contrast, Uber drivers are asked to speak only to reply to the customers' questions.

For Egyptian women, Uber seems to be a safer option in a country where sexual harassment is "epidemic" (PIVOVARCHUK \& SOLIMAN). Indeed, verbal harassment, as well as asking a female passenger whether she is married and staring at her suggestively through the mirror, seems to be a common taxi etiquette in Egypt. Uber, instead, seems to be more women-friendly. Female riders feel safer about the idea of being able to check the driver's name and picture and being able to report him to the company in case of sexual harassment. Unlike white taxi drivers, who are predominantly men, $10 \%$ of Uber drivers are women and the company has committed to hire more (BERGER). Besides, since October 2015, Uber Egypt partners with Harassmap, one of the country's pioneering anti-harassment organizations, to offer drivers a 5-minute training on what constitutes sexual harassment and how to avoid it (ibid.). Uber drivers are also encouraged to put a sticker on their car to affirm positive action against sexual harassment. Critics argue that the course should last longer, considering that Uber women drivers are obliged to take a 3-additional-minute course in which they are trained on how to defend themselves from sexual harassment. In the meanwhile, another taxi company named Pink has emerged on the streets of Cairo (VeSELINOVIS). It is a company that offers a taxi service driven by women for women, as an attempt to provide a more secure means of transportation for women in Cairo. Their cars are decorated in pink and equipped with GPS, a camera, and an SOS button. All the drivers wear bright pink T-shirts. Critics complain about the fact that their rates are very high and that gender segregation is not a solution against sexual harassment [ $\boldsymbol{\lambda}$ Male $\boldsymbol{\nu}$ s. Female].

Moreover, Uber offers a different way of navigating the city. Egyptian professional taxi drivers traverse the city by using certain streets and signposts for orientation. They usually drive confidently around the city of Cairo and remember streets by heart. As a consequence, riders usually rely on the driver's knowledge and ability to find the place. The Uber driver navigates the city using GPS. GPS provides riders with a higher sense of security and control on the route, as they can check their location in real time and they can make sure that the driver is not taking a longer route to ask for a higher fare. However, sometimes GPS is not 
able to identify every street in Cairo. Besides, being new to the business, some drivers are not used to driving by looking at the map displayed on their mobile. In this case, the rider may help the driver by directing him/her. In other words, in theory, GPS should be a precious tool to navigate the city; for some Uber drivers, however, it still represents a challenge.

Uber is preferred by many also for its method of payment. With white taxis, riders often complain that drivers intentionally break or rig the meters to cheat on the price. Very often, they pretend not to have change on them to gain some additional money on the ride. With Uber, the service is paid directly by the credit card that the customer registers on the website. However, given that in Egypt only $7 \%$ of the population can afford a credit card, the company has started a trial programme that allows customers to pay in cash by paying an additional fee for the service (BERGER).

As typical of the shared economy model, once the service has been delivered, Uber customers are asked to rate the driver and the car for other members of the Uber community, with 1 to 5 stars. The review is a way of empowering the customers, as they can denounce poor service or any possible inconvenience during the trip. But it is even more important for the driver: if he/she does not maintain a good score (4.3 over 5$)$ in the riders' reviews, he/she is automatically fired by the company. That is why Egyptian Uber drivers sometimes try to bribe the customer by offering perfumed tissues, sweets, or a cold drink.

It seems to be particularly young Egyptians who are satisfied with the service [ 7 Young vs. Settled]. A young man quoted in MadàMașr, for example, expresses his preference for Uber in these terms:

I prefer to use Uber rather than the white taxis. It's always on call, with a fixed rate for their fares, and they don't try to overcharge me. Their drivers take me wherever I want. Unlike some cab drivers, they agree to pick me up and drop me off right at my doorstep. (CHARBEL)

Not surprisingly, professional taxi drivers are far less enthusiastic about the service. In March, they hold a series of demonstrations in Muștafà Mahmūd square in Muhandisīn and block traffic in the neighbourhood to protest against the spread of Uber and Careem and similar private taxi companies. Their main count of indictment is that unlike them, Uber drivers are not licensed, and therefore they do not need to pay taxes for their cars and licenses, as regular taxi drivers have to. Besides, they are able to offer a cheaper rate per $\mathrm{km}$.

'Ādil Anwar, the driver quoted in MadàMașr, says that the competition with the foreign companies has driven him into debt. Indeed, this occurs in a period in which Egypt is undergoing a strong economic crisis and fuel prices are rising [ $\nearrow$ Dollar Crisis]. He affirms that

we want these private car companies to register their vehicles as licensed cabs, and to pay the same expenses that we professional drivers are obliged to pay. Or they can register themselves as private limousine companies, with extra fees for passengers. Otherwise, it's just unfair competition" (CHARBEL).

Shākir, the driver quoted in Egypt Independent, blames the government for launching the white taxi project in 2007 as an alternative to traditional black taxis, and handing it to corrupt businessmen and finance ministers who, Shākir claims, 
manufactured taxis that were off-specification, overpriced and had low-quality spare parts, therefore exacerbating the problem" (ELBEHARY $[b]$ ).

According to Shākir, taxi drivers are squeezed by monthly tariffs and taxes, and this affects the treatment of the passengers. It is because of this bad service that people resort to private companies like Uber and Careem. Another white taxi driver interviewed by Egypt Independent argues that Uber and Careem contribute to the deterioration of the current national economy, which is already a disaster. That is why people should avoid them.

The money I currently earn goes to supermarkets, butchers and greengrocers, meaning it will circulate within the Egyptian market, but when passengers pay their bills through Visa to Uber or Careem, the money is being channelled to foreign economies instead,

he maintains (ibid.). In response, an Uber Egypt press release issued on December 2, 2015, claimed that in the course of one year, the company facilitated 1 million rides in Egypt, and created work opportunities for more than 1,000 drivers per month. But taxi drivers are convinced that these job opportunities come at the expense of licensed taxi drivers (CHARBEL).

Egyptian taxi driver protests follow the outburst of similar protests by fellow taxi drivers all over the world. However, while in some countries like Tunisia, labour unions have managed to impede the spread of Uber, the Egyptian General Union for Land Transport Workers - an affiliate of the state-controlled Egyptian Trade Union Federation-has done nothing to protect the drivers.

Therefore, some taxi drivers choose to take justice into their own hands. In March, a taxi driver orders a private car using Uber, with a view to drawing the driver into a trap. The cab driver takes the Uber driver to the police station, demanding to see his license for providing such a service $[\nearrow$ Security $=$ Fear $($ Police State) $]$. However, the police cannot take action. Uber is regularly registered in Egypt as a technological company and it pays taxes on its revenues (ELBEHARY [a]). This unsuccessful attempt notwithstanding, Uber drivers have been victims of violent intimidations by professional taxi drivers. In addition, white taxi drivers have launched a new campaign aimed at raising the standard of their service to resist the competition. One of these campaigns is called "Take a ride, start afresh," aiming to improve the image of taxi drivers by promising passengers better service and a guarantee against bad practices like sexual harassment, smoking and meter fraud. Another campaign encourages drivers to put a sticker on their taxis saying, "A new beginning, kindly step on board," as a sign that the driver is a respectable one (ELBEHARY [b]).

The Uber model has inspired similar marketing models in other service areas. Belal El Borno (Bilāl al-Burnū) and Mahmoud El Maghraby (Maḥmūd al-Maghribī) have launched Yumamia (Yumāmiyya), the 'Uber of food.' The company gives Egyptian women the opportunity to sell home-made food through the website. El Borno explains:

You order your food and the request is dispatched to cooks around your area; when someone accepts the request, it informs you and sends you a notification with the cook\#s name and picture so you can get to know the person a little bit. (CairoScene [a])

زحز 21 (2021) - Themed Section In2016: *272-*277 
Yumamia not only gives Egyptian housewives the opportunity to become entrepreneurs by utilizing their skills in the kitchen, it also invests in its cooks by offering them cooking and food hygiene classes (with a certificate). Therefore, it might be used by women as a tool to start a career in the catering service. Likewise, the app Rakna which offers a parking-valet service on demand is soon to be released (CairoScene [b]). That means that the driver can indicate his destination shortly before arrival, and he/she will find a valet waiting for him/her to park the car. Whenever the customer is ready to leave, he will inform the valet through the app, and will get the car back. The app institutionalizes a service that so far has been provided by the so-called sāyis, who improvise themselves illegally as parking valets. No wonder then that the app developers are still thinking about ways to prevent the suyyās' revenge, just like the taxi drivers' vindication in the case of Uber. However, they point out that while Uber is harming a category of workers who are fully licensed and unionized, Rakna is dealing with the suyy $\bar{a} s$ who are doing the same activity without any permission and have no right to claim their ownership of the city space.

\section{Related Entries}

ARRAYS - Crowdfunding $\downarrow$ Dollar Crisis $\downarrow$ Gated Communities / Compounds $\downarrow$ The Honourable Citizen $\checkmark$ Mobile Phones Pop Music Zahma

Codes - Freedom vs. Constraint (Individuality vs. Collectivity) Male vs. Female Y Young vs. Settled CODES ColLAPSED $-\diamond$ Security $=$ Fear $($ Police State)

\section{References}

ANDEEL, Mohammed. Facebook Statement, February 11, 2016, <https://m.facebook.com/story.php? story_fbid=10156521793905224\&id=777560223>, accessed July 7, 2018.

ELBehARy Hend [a]. "Cairo White Cabs Reap the Harvest of Bad Service.” Egypt Independent, February 15,2016 , <http://www.egyptindependent.com/cairo-white-cabs-reap-harvest-bad-service/>, accessed July 7, 2018.

- [b]. "Taxi Drivers Launch Campaigns to Win Back Customers." Egypt Independent, March 15, 2016, <http://www.egyptindependent.com/taxi-drivers-launch-campaigns-win-back-customers/>, accessed July 7, 2018.

Berger, Miriam. "Uber Says It is Fighting Sexual Harrassment in Egypt, but the Causes Aren't Going Away." BuzzFeed News, January 17, 2016, <https://www.buzzfeed.com/miriamberger/ uber-says-itsfighting-sexual-harassment-in-egypt-but-the-ca?utm_term=.wylx6owZEN\#.srPJokxLrn>, accessed July 7, 2018

Cairo Scene Team [a]. "The Uber of Food Turns Egyptian Housewives into Entrepeneurs." Cairo Scene, February 1, 2016, <http://www.cairoscene.com/Eats/The-Uber-of-Food-Yumamia-TurnsEgyptian-Housewives-Into-Entrepreneurs> , accessed July 7, 2018.

— [b]. "Rakna: the Uber of Parking, Is Almost There." Cairo Scene, February 23, 2016, <http:// www.cairoscene.com/Geek/Rakna-The-Uber-of-Parking-Is-Almost-Here>, accessed July 7, 2018.

Charbel, Jano. "Taxi Drivers Protest Against Uber and Other App-Based Car Services.” MadàMașr, February 4, 2016, <https://www.madamasr.com/en/2016/02/04/feature/politics/taxi-driversprotest-against-uber-other-app-based-car-services/>, accessed July 7, 2018.

Hartmans, Avery, and Nathan McAlone. "The Story of How Travis Kalanick Built Uber into the Most Feared and Valuable Startup in the World." Business Insider, August 1, 2016, <http://www. businessinsider.com/ubers-history? IR=T/\#june-2010-uber-launches-in-san-francisco-at-the-time-it- 
cost-about-15-times-as-much-as-a-cab-but-you-could-request-a-car-in-san-francisco-by-sending-atext-or-pressing-a-button-it-quickly-became-a-hit-7>, accessed July 7, 2018.

al-Kнамі̄sī, Khālid. Taxi: Hawādīt al-mashāwīr. Cairo: Dār al-Shurūq, 2009.

Mubawwaba Mașrāwī. "Ishtaghal bi-'arabiyyitak ma'a 'Ūbir aw Karīm alf maskan." Mubawwaba Mașrāwī, June 16, 2016, <http://mobawaba.masrawy.com/jobs/other-fields/details/1625200/

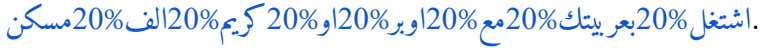

PivovarchuK, Anna, and Alia Soliman. "Fighting Back Against Sexual Harassment in Egypt." Fair Observer, December 7, 2016, <https://www.fairobserver.com/region/middle_east_north_africa/ sexual-harassment-egypt-endemic-99212/>, accessed July 7, 2018.

VESELINOVIS, Milena. "Tired of catcalls? Pink Taxi promises to drive women around Cairo peacefully." CNN, April 7, 2016, <https://edition.cnn.com/2015/12/09/africa/pink-taxi-cairo/index. html>, accessed July 7, 2018. 